\title{
Penile Cancer cN3 TNM Finding v7
}

National Cancer Institute

\section{Source}

National Cancer Institute. Penile Cancer cN3 TNM Finding v7. NCI Thesaurus. Code C89190.

Penile cancer with palpable fixed ing uinal nodal mass or pelvic lymphadenopathy unilateral or bilateral. (from AJCC 7th Ed.) 